\title{
Obsazení Porúř́i v roce 1923 a jeho hospodářský význam pro Německo a Velkou Británii
}

\author{
Zdenka JEŘÁBKOVÁ, University of Economics in Prague ${ }^{\mathrm{i}}$
}

\begin{abstract}
This study deals with the occupation of the German Ruhr area both in the context of recent developments in reparations negotiations and in term sof the economic repercussions in two selected countries - Germany and Great Britain. The Ruhr crisis had serious impacts on the German economy - a collapse of the German currency, an an increase in state indebtedness, which was subsequently alleviated by hyperinflation, a significant economic downturn and a loss of foreign markets. In contrast, Great Britain capitalized on the conflict by both improveming its economic output and increasing exports in its traditional industries.
\end{abstract}

\section{Keywords}

Economic relations, Germany, Great Britain,Ruhr crisis, 1923.

JEL Classification: E310, F510, N140, N440

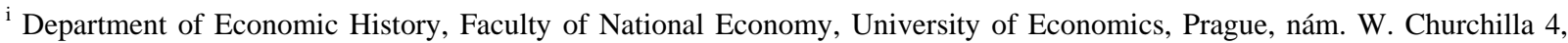
130 67, Prague 3, Czech Republic.

zdenka.jerabkova@vse.cz

This research was supported by the Science Foundation of the University of Economics under the project no. 503018.
}

\section{1. Úvod}

Politický a hospodářský vývoj zemí západní Evropy po první světové válce byl velmi významně ovlivněn problematikou stanovení a splácení reparací a válečných dluhů Německem vítězným mocnostem. Především ve Francii, Velké Británii, Německu a Belgii byla otázka reparací zcela zásadním tématem často řešeným na domácí politické scéně mimo jiné i pro to, že měla významný ekonomický podtext.

Otázka válečných náhrad je poměrně obsáhle zpracována z hlediska historie, politologie či práva, o čemž svědčí i nepřeberné množství odpovídající odborné literatury. Velká část pozornosti se ale soustřed'uje především na jeho politickou stránku bilaterální vztahy mezi vítěznými mocnostmi samotnými a/nebo s Německem. Poměrně málo českých i zahraničních soudobých textů se ale soustřed'uje na dopady této události do hospodářství jednotlivých zemí, resp. tyto dopady nejsou komplexně a detailněji analyzovány. V rámci této studie byla vybrána okupace rúrské oblasti jako vyvrcholení sporů o neplnění reparací Německem a jako událost mající bezprostřední konsekvence pro německé a britské hospodářství v první polovině 20. let. Ve snaze hlouběji analyzovat toto téma ekonomicky bylo vybráno časové období roku 1923, v němž jsou očekávány bezprostřední a nejtěžší dopady i s ohledem na několikaměsíční politiku pasivního odporu Německa.

Tato studie se zpočátku zabývá uvedením čtenáře do problematiky reparací a ve stručnosti jsou nastíněny události, které okupaci Porúř́i předcházely. Důraz je kladen na vyjednávání mezi představiteli Velké Británie, Německa a Francie a na vývoj jejich postoje k otázce obsazení rúrské oblasti. Snahou je nalézt odpověd' na otázky, jaké faktory určovaly průběh krize a zda bylo možno krizi v placení reparací řešit 
efektivnějším a rychlejším způsobem. V části analytické jsou metodou sondy analyzovány vybrané ukazatele průmyslu a zahraničního obchodu Německa a Velké Británie. Cílem je ukázat, jakého rozsahu byly mikroekonomické konsekvence, které okupace Porúŕí přinesla oběma zemím. Co se týče Velké Británie, lze očekávat spíše pozitivní důsledky, jelikož německé a britské podniky si v klíčových průmyslových odvětvích konkurovaly. Poté, co byla německá konkurence ochromena, britské podniky mohly expandovat. Naproti tomu v Německu by měly být důsledky jednoznačně negativní, jelikož rúrská pánev byla centrem německého těžkého průmyslu.

\section{2. (Ne)řrešení problémů $s$ reparacemi $v$ meziná- rodních jednáních}

Po prohře v první světové válce bylo Německo nuceno uzavř́t se spojenci Versailleskou mírovou smlouvu, ve které nejen že uznalo svoji odpovědnost za válku, ale také se zavázalo $\mathrm{k}$ zaplacení veškerých válečných výloh vítězných mocností (blî̌ze $\mathrm{k}$ vyjednávání viz napřr. Moravcová a Bělina, 1998). Souhrnná částka reparací byla po sérii vyjednávání stanovena ke konci dubna 1921 Reparační komisí ${ }^{1}$ na 132 miliard zlatých marek (Jordan, 1971). Tato suma měla být splacena částečně mimo jiné i hmotnými dodávkami - především dřeva, uhlí a dalších nerostných surovin a výrobkủ. Od této doby až do přijetí Dawesova plánu v roce 1924 se téma splácení reparací a obsazení Porúrúi jako ekonomické sankce stalo společným tématem mnoha mezinárodních jednání. Německo mělo již od počátku problémy s plněním těchto podmínek mírové smlouvy a několikrát bylo Reparační komisí vydáno prohlášení, že je $\mathrm{v}$ prodlení s pravidelnými splátkami svých závazků, a to i když ty byly opakovaně snižovány (Marksová, 2003).

Napjatá situace okolo reparací se vyhrotila v druhé polovině roku 1922, kdy německá strana ani peněžní, ani hmotné dodávky opět neplnila a již podruhé $\mathrm{v}$ krátké době žádala $\mathrm{v}$ půlce října o celkové moratorium na splátky reparací v trvání dvou a půl let. Svoji žádost ale nepodpořila zárukami splácení a zdůvodňovala ji především nutností stabilizace německé měny. Němečtí představitelé prohlašovali, že platby reparací významně poškozují domácí ekonomiku a především

\footnotetext{
1 Reparační komise byla výkonným orgánem spojenců založeným na základě Versailleské smlouvy a dohlížejícím na plnění reparačních povinností Německem a rozhodujícím o př́padných sankcích při neplnění. Byl $\mathrm{v}$ ní prrítomen zástupce Francie, Velké Británie, Belgie, Itálie a zpočátku i USA. Při rovnosti hlasů rozhodoval hlas francouzského delegáta.
}

německou měnu. Faktu vysoké inflace a devalvace německé marky si byli vědomi ekonomové jak ve Velké Británii, tak ve Francii. Velká Británie proto byla ochotna na moratorium přistoupit, aby Německo mohlo ozdravit svoji měnu a provést měnovou reformu. Velkou roli hrál i názor prosazovaný britským ministerským předsedou Lloydem Georgem, který tvrdil, že hospodářská prosperita Velké Británie (a potažmo Evropy) závisí také na př́znivém ekonomickém vývoji Německa. Německo bylo před válkou nejsilnější ekonomikou Evropy. Proto také byla Velká Británie téměř vždy ve svém př́istupu $\mathrm{k}$ Německu smírrlivější než Francie.

Francie důrazně protestovala proti povolení odložení splátek $\mathrm{v}$ obavě, že jakmile bude umořování válečných dluhů a reparací jednou pozastaveno, nebude již nikdy obnoveno. Francie si nepřála ekonomickou obnovu Německa, jelikož by to ohrozilo její vojenskou i hospodářskou bezpečnost (Lowe, 1994). Francouzský ministerský předseda Raymond Poincaré v tiskovém prohlášení z konce ř́ijna roku 1922 již po několikáté pohrozil nezávislou donucovací akcí Francie, pokud nebudou její finanční problémy řešeny úplným splácením reparací a válečných dluhi̊ (O’Riordanová, 2001). I přes toto silné prohlášení Francie nepočítala $\mathrm{s}$ tím, že by bylo nutné donucovací akci provést, jestliže budou ostatní spojenci hlasitě protestovat. Tento fakt byl podpořen i vyjádřením Poincarého, že chce okupací pouze pohrozit (O’Riordanová, 2001). Odložení plateb Francie podmínila tím, že spojencům musí být poskytnuty jisté záruky př́ijmů - např. možnost zabavovat část celních a daňových př́ijmů nebo kontrolovat těžbu uhlí a dřeva. Nakonec došlo $\mathrm{k}$ přechodnému odložení splátek reparací díky ochotě Belgičanů akceptovat místo bankovek německé pokladniční poukázky.

Britská zahraniční politika se v této době vyznačovala nekoncepčností a vyčkávací taktikou. Neschopnost britských představitelů zaujmout jasné stanovisko pramenila jak $\mathrm{z}$ vnějších, tak i vnitřních podmínek ovlivňujících britskou zahraniční politiku (blíže O‘Riordanová, 2001). Velká Británie, prezentovaná novým ministerským předsedou Bonarem Lawem, se rozhodla nevyjadřovat se jasně $\mathrm{k}$ možnosti rúrské okupace. A tato skutečnost $\mathrm{v}$ konečném důsledku paradoxně rozhodla o provedení vojenské akce v Porúríi.

Francie požadovala uskutečnit konferenci s cílem definitivně rozhodnout o okupaci Porúř́, ale Velká Británie se snažila její uspořádání zdržovat a s vidinou vyřešení situace učinila pokus o vtažení USA do tohoto problému. USA vyjádřily nesouhlas s okupací Porúř́i a naopak navrhly vytvoření komise pro posouzení schopnosti Německa reparace platit. Přestože byla vedena mnohá komplikovaná mezinárodní 
jednání, nebyla přijata žádná kvalitativní změna ve splácení a stanovení reparací, která by zabezpečila dostatečné splácení reparací poraženou stranou v budoucnu.

Ke konci roku 1922 bylo Německo v prodlení s dodávkami dřeva, což bylo i přes britské námitky formálně deklarováno Reparační komisí. Na předběžné konferenci spojenců $\mathrm{v}$ Londýně na počátku prosince 1922 mínil Bonar Law navrhnout snížení válečných dluhů Francii s tím, že Francie je pak recipročně sníží i Německu a Německo pak bude spolupracovat a platit. Odpověd' Poincarého na tento návrh však byla nesmlouvavá - Francie nemůže poskytnout německé vládě žádnou výhodu (O’Riordanová, 2001). Velká Británie se opět uchýlila ke zdržovací taktice. Německo prrišlo s novou nabídkou na moratorium, které by se uskutečnilo formou půjčky na krytí německých státních dluhopisů. Poincaré ji okamžitě odmítl a pohrozil okupací dvou německých měst.

V lednu 1923 měl být přijat nový reparační plán, který ale dosud nebyl ani dohodnut. Proto se počátkem ledna konala $\mathrm{v}$ Paříži schůzka mezi dohodovými mocnosti a Německem. Na ní Velká Británie přednesla, i navzdory předchozímu odmítnutí, konkrétní podobu svého návrhu odpuštění dluhu svým spojencům (tzv. Bonar-Law Plan). Tento plán měl Německu poskytnout poslední pomoc. Pokud by jím nebyl prijiat, Británie by souhlasila $\mathrm{s}$ donucovací akcií Francie. Při svých úvahách ale britská vláda nevěnovala dostatečnou pozornost požadavku Francie na poskytnutí bezpečnostních záruk na kontinentě. Francie proto prohlásila britský návrh za absolutně neprrijatelný a dále trvala na moratoriu zajištěném tzv. produktivními zárukami - jednalo se především o dodávky nerostných surovin a také průmyslových výrobků vyráběných $\mathrm{v}$ rúrských významných podnicích těžkého průmyslu, především hutnictví, hornictví, strojírenství (Meyer, 1987). Zároveň odmítla jakékoli další návrhy německé strany. Němcům nebylo ani umožněno přednést své návrhy. Pařížská konference tak skončila katastrofálním neúspěchem již po dvou dnech.

Reparační komise vydala 9. ledna 1923 prohlášení, že se zpozdily dodávky uhlí, a zároveň rozhodla o uvalení ekonomických sankcí - pro hlasovali členové Francie, Belgie a Itálie, naopak Velká Británie byla proti. Pravidelné odvádění reparací mělo být na jedné straně sankcionováno a na druhé zabezpečeno okupací německého území v okolí řeky Rúr. ${ }^{2}$ Takto měly být zajištěny produktivní záruky plnění, limitována

\footnotetext{
2 Dle Wiedemanna (1927) se jednalo o území o rozloze 30000 tis. $\mathrm{km}^{2}$, na kterém žilo téměř 6 mil. obyvatel.
}

hospodářská i politická síla Německa a zvýšena bezpečnost na francouzské východní hranici.

Den před obsazením Porúríi Francouzi informovali německou stranu o uskutečnění sankce nótou, $\mathrm{v}$ níž bylo podotknuto, že: Zminěná opatření (rozuměj obsazeni Porúrí - pozn. autora) jsou učiněna na základě (...) Versailleské smlouvy. Ze strany Francie neznamenají vojenskou okupaci nebo okupaci politického charakteru. (...) Francouzská vláda posílá do Porúrí pouze jednotky potřebné $k$ zabezpečeni delegace (MICUM - pozn. autora, viz dále) a jako záruku výkonu jejího mandátu. (...) pokud by mistni úrady vytvář́ly at’ už vlastním př́činěním nebo nečinností jakékoli problémy $v$ materiálním a ekonomickém životě oblasti, všechna donucovaci opatření a všechny sankce, jež by byly považovány za nutné, by byly učiněny (BA R1603/2872).

\subsection{Zajištění plateb reparací obsazením Porúrú}

Dne 11. ledna 1923 vstoupili členové Mezispojenecké komise pro kontrolu továren a dolů (Mission Interalliée de Contrôle des Usines et des Mines - dále MICUM) v doprovodu francouzských a belgických vojenských jednotek na území Porúrí. Přítomna byla i skupina italských inženýrů. Není bez zajímavosti, že tajné rozkazy o př́pravě na okupaci Porúríi byly veliteli rúrské operace, generálu Degouttovi, zaslány již 3. ledna 1923, tedy den před ztroskotáním jednání v Paříži (Fischer, 2003). MICUM byl svěřen dohled nad těžbou uhlí a plněním dodávek uhlí a dřeva a dalších komodit. Jakýkoli odpor místních podnikatelů byl Francouzi většinou řešen zabavením majetku často se jednalo o doly a továrny. Postupně bylo Porúř́i uzavíráno obchodu, byla vyhlášena vnější cla a vydány zákazy vývozu důležitých nerostných surovin. Velký problém pro Francouze představovala doprava zabavených surovin - oprávněně se obávali stávek v železniční dopravě na okupovaných územích proto byla vytvořena vlastní železnice Régie. Ta obsluhovala všechny železniční dráhy na okupovaných územích, vyjma britského, kde železnice dále fungovala pod německou Reichsbahn (Pawleyová, 2007).

Britská vláda zaujala k vpádu francouzských a belgických jednotek postoj tzv. benevolentní neutrality, spočívající $\mathrm{v}$ nevměšování se do tohoto sporu a neprotežování ani jedné z jeho stran (BA R43I/208). Představitelé Velké Británie ve spojeneckých komisích vydávajících opatření pro obsazená území (Reparační komise a Mezispojenecká rýnská vysoká komise - Interallied Rhineland High Commission - 
dále Vysoká komise ${ }^{3}$ ) se měli zdržet rozhodnutí, která by se jakkoli týkala otázky Porúríí.

Britská kolínská zóna byla svou polohou a především železničním uzlem Kolín velmi významnou pro dopravu vlaků na francouzské území, proto byla s Francouzi uzavřena dohoda, která umožňovala přejezd celkem dvanácti francouzských vlaků v obou směrech každý den. Problémem bylo také vymáhání celních sankcí, které Francie na svých územích zavedla. Bylo obtížné je vybírat na britském území bez toho, aby se nejednalo o stranění Francii. Nakonec bylo dohodnuto, že tato cla budou vymáhat francouzští úředníci bez přičinění britské správy.

\subsection{Zahájení pasivního podporu německou stra- nou}

Německá vláda se nejdříve spoléhala na britský a americký tlak vůči Francii, aby ta ustoupila a své jednotky stáhla. Fischer (2003) uvádí, že (...) kanclér Cuno se spoléhal v marné naději na zprostředkovatele Velké Británie a USA, místo toho byl konfrontován s invazí s nejasným trváním, a jež v podstatě oddělila Německo od jejího industriálního srdce. Velká Británie protestovala vágním způsobem, což samozřejmě ke změně francouzského postoje nepřispělo. Německá vláda, ocitnuvší se bez zahraniční podpory reagovala, 19. ledna 1923 na vpád jednotek výzvou k již všeobecně podporovanému pasivnímu odporu na obsazených územích (mimo britské zóny). Vydala nařízení, ve kterém mimo jiné prohlašovala: $V$ důsledku toho (rozuměj porušení mezinárodního práva a Versailleské smlouvy Francií a Belgií - pozn. autora) jsou př́kazy a nařizení, které budou v prủběhu této akce vydána na německých úr̆adech, neprávoplatná. (...) z nařizení okupačnich sil nevyplývá žádná povinnost, nýbrž je třeba se ř́ldit výhradně pokyny vaši vlastní vlády. To platí také pro úredniky dřive obsazených oblastí ve všech opatřeních, která jsou v rozporu s ustanoveními Rýnských dohod (Hürten, 2003).

Jednalo se o prŕkaz naprostého bojkotu jakékoli spolupráce s francouzskými a belgickými představiteli na německém území pod cizí správou, a to tedy nejen $\mathrm{v}$ Porúríi, ale i v dříve obsazených oblastech. Berlín začal vydávat zákony a nařízení platná pro obsazená území, zatímco dříve je vydávala Vysoká komise. Německá vláda se zavázala $\mathrm{k}$ materiální a finanční podpoře rúrského boje. Z již prázdné státní pokladny Berlín financoval mzdy a platy zaměstnancủm a ušlé zisky podnikům. Fiskální expanze byla činěna především na vrub zvýšené emise oběživa a astronomických

\footnotetext{
3 Vysoká komise byla podobně jako Reparační komise výkonným orgánem spojenců vzniklým v souvislosti s Versailleskou mírovou smlouvou. Vydávala legislativní opatření platící na německém území obsazeném spojenci.
}

temp růstu míry inflace. Financování pasivního odporu se stávalo čím dál méně udržitelné a zastavení výrob ruinovalo německou ekonomiku (blíže viz Hospodářské důsledky pro Německo). Francie v Porúurí nezískala takové produktivní záruky, jak očekávala, naopak zajišstování dodávek reparací bylo velmi náročné a nákladné. Obě země se ekonomicky velice rychle vyčerpávaly, čehož dokladem mohou být kolapsy jak franku, tak i marky, rostoucí inflace v Německu a zvyšování zadlužení obou států (blíže viz část 3.1).

Představitelé Velké Británie začínali pod diplomatickým tlakem (např. z Itálie či Ruska), pod vlivem nepř́iznivé domácí ekonomické situace, nespokojenosti občanů s neschopností vlády a problémů s udržitelností této politiky měnit politiku benevolentní pasivity směrem $\mathrm{k}$ aktivnějšímu přístupu - z pouhého diváka (se méla Velká Británie zménit - pozn. autora) na velmi užitečného zprostředkovatele, moderátora vyjednávání (O’Riordanová, 2001). V Británii došlo ke změně ministerského předsedy, nemocného Bonara Lawa nahradil Stanley Baldwin. Ke konci dubna 1923 se tedy charakter britské zahraniční politiky změnil, ale bylo již prŕlišs pozdě, žádná ze stran nechtěla ve sporu ustoupit.

Podmínkou Francouzů k dalšímu vyjednávání o opuštění Porúř́ bylo ukončení pasivního odporu, Němci ho naopak podmiňovali bezpodmínečným opuštěním Porúř́i spojenci. Britové začali naléhat na Německo, aby poslalo své návrhy pro jednání o okupaci Porúríí. Stalo se tak počátkem května 1923. Nicméně Francie, podporována Belgií, tyto návrhy opět odmítla. Nové německé návrhy dorazily do Londýna začátkem června. Byl $\mathrm{v}$ nich mimo jiné vysloven souhlas $\mathrm{k}$ prozkoumání německé schopnosti platit reparace nestrannou komisí (viz návrh USA z prosince 1922 výše), byly v něm poskytnuty garance pro zajištění plateb reparací a také nabídka $\mathrm{k}$ usporáádání mezinárodní konference o reparacích. Nicméně hlavní požadavek na ukončení pasivního odporu nebyl zmíněn. Francie s Belgií reagovaly vysláním svých ambasadorů, aby oslovili vládu Velké Británie s požadavkem na podporu okamžitého ukončení pasivního odporu.

Británie se tomuto požadavku bránila, jelikož by to znamenalo stranění francouzské straně sporu a také to, že je okupace Porúríi považována Velkou Británií za oprávněnou. Naproti tomu kdyby se Velká Británie přiklonila na stranu Německa, znamenalo by to, že je okupace chápána jako nezákonná, resp. neodpovídající Versailleské smlouvě. Vyjednáváními stanovená konečná odpověd' Německu obsahovala vyjádření, že Británie podpoří Francii a Belgii v rúrském konfliktu, pokud nebude přezkoumána schopnost Německa splácet reparace a nebude ukončen pasivní odpor, 
s př́slibem, že pokud jej Německo ukončí, budou vojenské jednotky z Porúrí bez prodlení evakuovány. Francie se ale stále bránila jednáním, jestliže nebude ukončen pasivní odpor jako první. Zdálo se, že se situace oproti počátku roku 1923 nijak nezměnila.

Velká Británie poslala v první polovině srpna Francii a Belgii ostrou nótu kritizující jejich politiku vůči Německu a jasně se vyslovující proti vojenské okupaci Porúríi (Von Wuthenau, 1924). Francie reagovala na nótu rozsáhlou kritikou britské nekonzistence, především Británii vytýkala, že byla připravena okupovat Porúř́i v roce 1921, ale nikoli v roce 1923 (BA R43-I/452). Nedošlo ale $k$ vážnému narušení vzájemných vztahů a koncem srpna se opět zájmy obou států začaly přibližovat. Po schůzce 19 . zárí mezi Poincarém a Baldwinem, kdy byla deklarována vzájemná shoda, bylo jasné, že Británie přijala francouzskou politiku. Britská politika tak opět vypadala nekonzistentně a poskytla po ukončení pasivního odporu Francii jedinečnou př́ležitost vytěžit ze stávající situace nejvíce a bez pomoci Velké Británie.

Volání Německa o pomoc ve vyjednávání nebylo Británií vyslyšeno a Německo se začalo zajímat o vyjednávání prŕmo s Francií. Od počátku záríi 1923 se snažila německá vláda vyjednávat $\mathrm{s}$ francouzskou stranou, bez valného úspěchu. Také němečtí průmyslníci vedli jednání s francouzskými představiteli v Porúríí, jednalo se o dohody mezi podnikateli v Porúŕí a MICUM, které by zabezpečovaly dodávky německých komodit a zboží Francii. Jakmile byl pasivní odpor odvolán, němečtí podnikatelé začínali tyto dohody v mnohem větším počtu podepisovat.

\subsection{Zrušení pasivního odporu a ochota Německa platit}

Obrat $\mathrm{v}$ německém př́stupu $\mathrm{k}$ okupaci Porúŕí nastal po změně vlády v polovině srpna 1923, kdy Wilhelma Cuna na místě kancléře vystrrídal Gustav Stresemann. Po jeho nástupu do funkce se uskutečnila schůzka představitelů německé vlády, Porýní a Porúrúi. Na ní bylo konstatováno, že za daného stavu státního rozpočtu a hyperinflace nelze pokračovat $\mathrm{v}$ pasivním odporu. Toto rozhodnutí znamenalo vstřícný krok pro další vyjednávání s Francií. Vláda zdůvodnila konec podpory obsazeným územím ve svém prohlášení z 26. záríi 1923 takto: $V$ uplynulém týdnu dosahovala pomoc pro Porýni a Porúrí sumy 3500 bilionu (inflačnich pozn. autora) marek. V tomto týdnu se očekává, že se tato částka nejméně zdvojnásobí. (...) Hospodářský život je v obsazeném i neobsazeném Německu rozvrácen. Velice vážně hrozi nebezpečí, že při setrvání v současném stavu bude nemožné, aby vznikla spořádaná měna, byl zachován hospodářský život a byla zajištěna holá existence našeho národa. (...) Aby byl život národa a státu zachován, stojíme dnes před trpkou nutností boj ukončit. (Hürten, 2003, popř. BA R43-I/215).

Pasivní odpor tak skončil v čase, kdy se vláda snažila ozdravit německou měnu, právě proto, aby ho udržela. Ačkoli pasivní odpor zvyšoval v Německu ekonomické i sociální napětí, každá sociální vrstva vnímala, že právě ona přináší největší oběti této politice, jeho odvolání bylo německým obyvatelstvem vnímáno jako zrada a Stresemann byl nucen podat demisi. Nový kabinet ke konci listopadu 1923 vytvořil Wilhelm Marx se Stresemannem jako ministrem zahraničí. Francouzské a belgické jednotky v obsazených oblastech dále zůstaly a čerpaly platby reparací ve finanční a hmotné formě.

Britský postoj $\mathrm{k}$ vývoji v Německu byl v této době velmi nesmlouvavý - kolabování politického i ekonomického systému bylo považováno za důsledek špatných rozhodnutí německých i francouzských představitelů. Velká Británie chtěla, aby si toto Francie i Německo uvědomily a ona pak mohla diktovat podmínky ohledně vyrovnání válečných nároků s Německem. Její politikou tedy bylo nevměšování se do rúrské krize, a to ani např. s potravinovou pomocí, jelikož by se tak pouze oddalovala doba, kdy si musí obě strany sporu uvědomit svoji chybu. Představitelé Velké Británie zastávali názor, že Francie nemá připravenu alternativní politiku poté, co bude opuštěn pasivní odpor. Později se také ukázalo, že tato domněnka měla reálný základ. Velká Británie se začala od záŕí 1923 čím dál tím více stavět do opozice vůči Francii. Britská vláda měla informace, že Francie uzavírá s německými průmyslníky prostřednictvím MICUM dohody ${ }^{4}$, podporuje separatistická hnutí v Porýní a dalších oblastech s cílem dosáhnout jejich odtržení od Německa a usiluje o založení nové emisní banky v Porýní.

Dohody mezi podnikateli a MICUM o dodávkách surovin a průmyslových výrobků Velká Británie vnímala jako dočasnou záležitost a nesouhlasila se zakládáním nové banky ani s pomocí separatistickým hnutím. V těchto otázkách spíše podporovala německou vládu. Britové si byli velmi dobře vědomi toho, jak značně byla německá ekonomika poškozována okupací Porúríi. Poté, co byl odvolán pasivní odpor, se snažili Němcům napomáhat $\mathrm{v}$ jejich úsilí dostat Porúř́ zpět pod svou kontrolu.

\footnotetext{
${ }^{4}$ O`Riordanová (2001) uvádí, že ke konci října 1923 byly uzavřeny dohody se 17 \% německých průmyslníků v Porúríi. S tzv. šesti nejvýznamnějšími rúrskými průmyslníky byly dohody podepsány až v listopadu 1923 a byly průběžně obnovovány až do zavedení Dawesova plánu na počátku roku 1925.
} 
Velká Británie po celou dobu sledovala komplexnější téma a to vyjednávání o reparacích, do kterých opět mínila zapojit i Spojené státy jako záruku dlouhodobosti a neměnnosti. Stanovení adekvátních reparací mělo být základním stavebním kamenem budoucí politické a ekonomické stability Evropy. Rozhodnutí vtáhnout Spojené státy do dění v Evropě se následně ukázalo jako dobrý tah, Francie poté, co se ocitla pod britským, ale i americkým a belgickým tlakem, ustoupila ze svých požadavků vůči Německu. K tomuto zahraničnímu tlaku se totiž přidaly i vlastní ekonomické problémy - především depreciace francouzského franku - a neúspěch separatistických hnutí v Porýní. K měnovým intervencím potřebovala Francie zahraniční půjčky, které především očekávala od USA a Velké Británie. Ty je však chtěly poskytnout až po vstřícném kroku Francie vůči Německu.

Bezprostředně po ukončení pasivního odporu bylo třeba $v$ Německu vyřešit minimálně tři významné problémy: uskutečnit měnovou reformu, vytvořit plán reparačních plateb, odsunout cizí jednotky z německého území (akutně z Porúríi). Otázka ozdravění německé měny byla vyřešena poměrně snadno. V polovině listopadu 1923 byla v Německu zavedena nová německá měna Rentenmark, jež byla kryta zemědělskými, průmyslovými a obchodními aktivy, a založena nová emisní banka Rentenbank. Zároveň byla Německu poskytnuta zahraniční půjčka ve výši 500 mil. zlatých marek, určená $\mathrm{k}$ ozdravení měny a německá měnová $i$ rozpočtová politika se ocitly pod dohledem zahraničních expertů. Podrobněji se měnové reformě věnuje část 3.1 .

\subsection{Vytvoření Dawesova plánu}

Gustav Stresemann své diplomatické snahy zaměřoval na revizi reparací a stanovení jejich splátek podle aktuální hospodářské situace Německa na základě znění Versailleské smlouvy. Podle Článku 234 totiž měla Reparační komise čas od času zkoumat platební schopnost Německa. Stresemann argumentoval tím, že splátky musí být minimálně pozdrženy, než bude provedena měnová reforma. Německo platilo reparace na hranici svých možností, a právě důsledným spláceným reparací chtěl doložit jejich nesmyslnost. První kroky k vytvoření nového plánu plateb reparací byly učiněny již v druhé polovině října 1923, kdy Velká Británie vyzvala ostatní státy, aby byly přizvány k účasti na jednání Spojené státy. Francouzi byli spíše proti, Belgičané a Italové vyslovili souhlas. Nicméně na jednání Reparační komise $\mathrm{v}$ polovině listopadu téhož roku Francouzi sami podali návrh na přezkoumání německé schopnosti splácet reparace podle amerického vzoru. Dne 30. listopadu bylo Reparační komisí rozhodnuto, že budou ustanoveny dva výbory, které se budou zabývat jak otázkou schopnosti platit reparace a stabilizací německé marky
- výbor pod vedením amerického finančníka a brigádního generála Charlese Dawese -, tak i vývozem německého kapitálu a dovozem zahraničního kapitálu do Německa - výbor pod vedením Reginalda McKenny, britského finančníka.

$\mathrm{Z}$ hlediska stanovených úkolů byl mnohem důležitější Dawesův výbor. Obě komise začaly pracovat od ledna 1924. Konečná Dawesova zpráva byla vydána 9. dubna 1924 a navrhovala nejen nové uspořádání německé měny, ale také nový systém splácení reparací. Celková částka závazků ani délka splácení nebyly stanoveny, nicméně bezprostředně následující platby reparací byly co do velikosti sníženy. Pravidelné splátky se pohybovaly od 1 mld. zlatých marek od následujícího roku až po 2,5 mld. marek v roce 1929 a stoupaly $\mathrm{v}$ závislosti na tzv. indexu prosperity růstu ekonomického výkonu. $\mathrm{Z}$ poloviny měly být financovány ze státního rozpočtu a $\mathrm{z}$ poloviny z obligací Reichsbahn a průmyslových podniků (Moravcová, 2006). Toto schéma mohlo fungovat za podmínky, že bude Německu poskytnuta mezinárodní půjčka ve výši 800 mil. marek určená na obnovu ekonomiky a také bude představovat základ pro splácení reparací.

Rovněž měla být s ohledem na situaci v Porúurí obnovena hospodářská jednotnost německého území a sanován německý státní rozpočet (blíže viz Steitz, 1993, popř. Meyer, 1987). Německé finance měly být pod pohledem zahraničních odborníků. Do splátek reparací se nyní začaly promítat mimo jiné i náklady na okupaci či náklady na provoz Reparační komise (do té doby je Německo platilo bez ohledu na reparace). Zabezpečení deviz pro splácení reparací již nebylo úkolem německé vlády, ale převzal je tzv. reparační agent. Spojené státy americké také přislíbily účast soukromého kapitálu v Německu, který byl velice významný při hospodářské obnově ve 20 . letech.

Německo vnímalo Dawesův plán jako vhodný nástroj pro vynucení si odchodu francouzských jednotek a jako záruku co nejnižších reparací. Počítalo s tím, že pokud se reparace stanou neúnosnými, budou opět vyjednány nové podmínky splácení. Ačkoli Dawesův plán nebyl konečným řešením, ale pouze překlenovacím opatřením, podařilo se dosáhnout odpolitizování reparací a jejich nastavení odpovídalo reálným možnostem německé ekonomiky.

Postupně všechny státy vyslovily s Dawesovou zprávou souhlas, ale Francie nechtěla ukončit okupaci Porúrí. Situace se změnila teprve až v květnu 1924, kdy do křesla premiéra usedl Edouard Herriot, který se jasně vyslovil pro podporu plánu a pro ukončení okupace Porúríí, jakmile bude Dawesův plán v účinnosti. Bylo dohodnuto, že konkrétní kroky týkající se implementace Dawesova plánu budou dojednány na 
konferenci v Londýně. Tato konference začala 16. července 1924 a Německo bylo na ni poprvé přizváno jako rovnoprávný účastník. Bylo rozhodnuto, že pokud se bude jednat $\mathrm{v}$ Reparační komisi o věcech týkajících se Dawesova plánu, bude vždy přítomen představitel USA. Sankce budou aplikovány pouze v př́ipadě flagrantního porušení reparačních povinností. Jakékoli spory měly být řešeny Mezinárodním soudem. Porúríi mělo být do roka po zavedení Dawesova plánu opuštěno vojáky a mělo být obnoveno jeho ekonomické a politické zapojení do německého státu.

V době trvání Dawesova plánu se německé vládě dařilo svým závazkům dostát, a to především díky mohutnému př́livu amerického kapitálu ve formě krátkodobých investic. Německému hospodářství se také začala vyplácet provedená měnová a rozpočtová reforma a další hospodářsko-politická opatření učiněná za vlád Gustava Stresemanna a Wilhelma Marxe. Také sevření francouzsko-belgickými jednotkami v obsazených oblastech se uvolňovalo. Ty postupně Porúríi opouštěly, poslední cizí voják odešel koncem srpna 1925.

Obsazení rúrské oblasti bylo uskutečněno souběhem několika okolností, kdy jednu z hlavních rolí hrálo několik pochybení na straně Velké Británie. Dá se říci, že pokud by se její představitelé chovali jinak, bylo by možné rúrské krizi zabránit. Pokud by se Velká Británie na počátku sporu přiklonila na stranu Francie nebo Německa, druhý stát by ustoupil. Při pohledu na jednání mezi spojenci nebo mezi spojenci a poraženými zeměmi je patrné, že velice důležitou roli při nich hrála jednota. Pokud Francie a Velká Británie byly jednotné $\mathrm{v}$ postoji vůči Německu, Německo jim nikdy neodporovalo. Naopak pokud byla Velká Británie a Německo v opozici vůči Francii, ta nikdy nejednala proti jejich vůli (Marksová, 2003). Ovšem britské volby přinesly změnu ministerského předsedy - Lloyda George nahradil Bonar Law. Ten svou neobratnou diplomacií zajistil Francii podporu Belgie i Itálie.

Významná byla i skutečnost, že Velká Británie nikdy zcela nepochopila obavy Francie z Německa a jeho hospodářské a vojenské síly. Britští predstavitelé si nikdy neuvédomili, že (v souvislosti s rúrskou krizí - pozn. autora) jsou svédky nákladného prodlouženi prvni světové války (Marksová, 2003). Británie nechtěla poskytnout Francii bezpečnostní záruky týkající se Německa, jelikož by mohla být zatažena právě do podobného sporu, jako byl ten rúrský. Francie, kterou nutily její válečné dluhy k pokusům získat $\mathrm{z}$ německého dlužníka co nejvíce ze svých pohledávek, sama procházela náročnou hospodářskou obnovou, kterou byla nucena financovat půjčkami. Okupace Porúŕí byla poslední možností, jak vymoci požadované reparace.
Podle Marksové (2003) bylo obsazení Porúurí neadekvátně prodlouženo dvěma okolnostmi. První byla skutečnost, že Poincaré nedokázal zcela izolovat Porúří od neokupované části Německa, a tamější obyvatelstvo tak bylo v pasivním odporu podporováno finančně i materiálně zvnějšku. Druhou okolností byla nerozhodnost Velké Británie, které se projevením jasného postoje nemínila dostat do sporu ani s Francií ani s Německem. Je možné, že rozhodnější postoj Británie by mohl přimět Německo k placení reparací. Britská politika benevolentní neutrality také zcela jistě podpořila německý odpor $\mathrm{v}$ průběhu rúrské krize.

\section{Hospodářské důsledky pro německé hospodářr- ství}

Při analýze hospodářských dopadů rúrské krize je třeba si uvědomit, že po první světové válce byly mezinárodní hospodářské vazby částečně zpřetrhány. Zahraniční obchod tlumila ochranářská opatření, měny se potýkaly s vysokou inflací. Státní rozpočty mnohých zemí trpěly deficity a vzrůstajícím domácím i zahraničním zadlužením. Země rekonstruovaly své průmyslové kapacity a obnovovaly zemědělskou výrobu. Dopady rúrské krize byly mnohem patrnější v evropském než celosvětovém měřítku a samozřejmě se jejich vliv mísil s jinými dopady poválečných opatření, která byla činěna $\mathrm{v}$ závislosti na aktuální politické a ekonomické situaci.

Cílem následujícího textu je prozkoumat možné ekonomické důsledky obsazení Porúř́i pro evropské průmyslové státy a především německou ekonomiku. Nejprve bude zkoumán vliv na německé hospodářství jako celek. Následně bude použita metoda sondy, pomocí níž bude analyzován vývoj ve vybraných průmyslových odvětvích. Obdobně bude postupováno i v př́ípadě zkoumání účinků na britskou ekonomiku. Nejtěžší dopady lze očekávat $\mathrm{v}$ podnicích těžkého průmyslu, jelikož právě ty se v okolí řeky Rúr koncentrovaly. Také zahraniční obchod Německa mohl být výrazně negativně ovlivněn, a to jak zvýšením dovozu, tak i snížením vývozu.

Jedním z nejviditelnějších důsledků rúrské okupace $\mathrm{v}$ Evropě byl růst cen některých surovin $\mathrm{v}$ důsledku zaostávání nabídky za poptávkou. I přes zvýšenou produkci $\mathrm{v}$ jiných zemích využívajících obsazení Porúŕí se nepodařilo vysokou poptávku uspokojit a výsledkem byl poptávkou tažený růst cen vybraných komodit a výrobků, jejichž byla rúrská oblast významným producentem. Jednalo se především o uhlí, 
koks, železnou rudu a další nerostné suroviny a průmyslové výrobky. ${ }^{5}$

Mezi další obecné makroekonomické konsekvence lze zařadit nárůst německých dovozů $\mathrm{v}$ některých komoditách, $\mathrm{v}$ jiných zase pokles německé poptávky (mající reciproční odezvu na evropských trzích), všeobecný pokles kupní síly obyvatelstva $\mathrm{v}$ důsledku zvýšení cen, zhoršený vývoj kurzů evropských měn, přerušení obnovy evropských ekonomik - plýtvání zdroji potřebnými pro obnovu, ztrátu bohatství, a v neposlední řadě i zvýšenou nejistotu (Schultze, 1927).

Míra projevu a charakter dopadů se lišily v závislosti na propojenosti s německou ekonomikou. Například Velká Británie částečně dokázala nahradit německé vývozy a z nastalé situace spíše těžila (viz část 4.), naproti tomu např́klad Spojené státy americké nebyly přímo výrazně rúrskou krizí ovlivněny, i když američtí investoři kolapsy německé marky a francouzského franku utrpěli značné ztráty na svém jmění. Tato stat' však nemá za cíl tyto všechny širší aspekty postihnout, nýbrž se zabývá pouze vybranými dopady na hospodářství Německa a Velké Británie.

\subsection{Kolaps německé měny a náklady rúrské okupace}

Německo se v rámci Versailleské smlouvy zavázalo k pravidelným peněžitým platbám i hmotným dodávkám reparací. Tyto finanční toky jednoznačně vyčerpávaly německé zásoby devizových rezerv a kurz marky díky převodu do deviz ve velkých sumách a později i zvýšenou inflací devalvoval. Jasné spojení mezi platbami reparací a hyperinflací je mnohými ekonomy i historiky zpochybňováno (napřr. Fischer, 1984 nebo Lowe, 1994), nebot' nelze opomenout úmysl vlády měnu oslabovat za účelem snížení státního zadlužení. Měna byla systematicky a vědomě ruinována vládou s cílem dosáhnout umoření domácího i zahraničního dluhu zvýšenou inflací a depreciací kurzu.

\footnotetext{
${ }^{5}$ Podle údajů Říšského kancléřství (R43-I/36) činily podíly na evropské těžbě železné rudy u Francie 44,5\%, Velké Británie 16,8 \%, Španělska 10,2 \%, Švédska 7,7\%, Německa $7,5 \%$ (výpočty vycházejí z průměru $\mathrm{v}$ roce 1913). Na evropských zásobách železné rudy měla největší podíl Francie 57 \%, Velká Británie 17 \%, Švédsko 8,1\%, Německo $8 \%$. Podle průměru z ledna až října 1922 bylo pořadí největších producenti̊ uhlí následující: Anglie $48 \%$, Německo 26,5 \%, Francie (se Sárskem) 9,3 \%.

Ruge (1982) uvádí, že pouze samotné Porúř́ disponovalo $72 \%$ zásob černého uhlí, 54 \% dobývací kapacity železné rudy a produkovalo 53 \% celkové výroby oceli. Naproti tomu Michalka (1987) dokládá, že území obsazená v rámci Versailleské smlouvy představovala pouze $50 \%$ zásob železné rudy, $25 \%$ zásob černého uhlí.
}

Již před okupací Porúř́i se německá míra inflace aproximovaná indexem velkoobchodních cen mezi lety 1920 a 1921 vymykala vývoji v ostatních zemích západní Evropy, jak je patrné z tabulky 1. Vrchol v cenách velkoobchodníků lze obecně zaznamenat $\mathrm{v}$ roce 1920 , kdy se po válce nahromaděná poptávka domácností po spotřebním zboží a také firemní poptávka po investicích naplno promítly do zvýšení cen (Fischer, 1984). Od následujícího roku 1921 pak nastal pokles cen trvající až do roku 1922 v souvislosti s tím, že se anglická a americká centrální banka rozhodly bojovat proti rostoucí cenové hladině restriktivní měnovou politikou.

V Německu byl ale vývoj zcela jiný. K poklesu cenové hladiny nedocházelo. Naopak od poloviny roku 1922 se již začínaly naplno projevovat prŕiznaky hyperinflace, které čím dál více nabývaly na intenzitě. Hyperinflace byla $\mathrm{v}$ první fázi primárně důsledkem plateb reparací a také nadměrné emise hotovosti v důsledku zvýšených výdajů státního rozpočtu po válce. Tento faktor byl v roce 1923 mnohem významnější, jelikož platby reparací byly zastaveny a nadměrné tištění peněz bylo výrazně podpořeno závazkem vlády v lednu 1923 financovat a podporovat pasivní odpor na obsazených územích. Měna velice rychle prrestala fungovat jako uchovatel hodnoty a postupně i jako prostředek směny. Balderston (2002) uvádí, že ceny se mezi červnem 1922 a červnem 1923 průměrně zvyšovaly o téměř $2 \%$ denně, mezi červencem 1923 a listopadem 1923 až o 12 \% v průměru za den. Růst úhrnné cenové hladiny lze také ilustrovat na vývoji měnového kurzu marky $\mathrm{k}$ americkému dolaru, popř. ke všem devizám; viz tabulka $7 \mathrm{v}$ př́loze.

V období pádivé inflace až hyperinflace docházelo $\mathrm{k}$ mnoha negativním jevům - jedním z nich bylo přerozdělení bohatství směrem ke dlužníkům (především státu a podnikům) a díky devalvaci měny i k vývozcům. V Německu také nejvíce trpěla neanticipovanou hyperinflací střední třída, když došlo k vymazání jejích úspor a hodnot držených v cenných papírech. Pokles reálných př́imů lze zaznamenat u všech společenských vrstev, ale nejvíce to bylo citelné u obyvatel závislých na fixních platech a podporách od státu. Naproti tomu se v důsledku hyperinflace alespoň zpočátku nezvyšovala nezaměstnanost a byla podpořena tvorba reálných investic. Balderston (2002) uvádí jako př́klady rozšiřování kapacit v ocelářství, lodní dopravě či na dráze. Podnikatelé se snažili hyperinflace využít ke koupi upadajících podniků. $^{6}$

\footnotetext{
${ }^{6}$ Př́ḱladem může být průmyslník Hugo Stinnes, kterému se podařilo své impérium významně rozšíriit, aby se mu v následujícím roce rozpadlo (blíže Prüfer a Tomin, 1962).
} 
Hyperinflaci odstranila měnová reforma, $\mathrm{v}$ rámci níž byla zavedena $\mathrm{v}$ polovině listopadu 1923 nová měna Rentenmark (RM), která se převáděla poměrem 1 : bilionu papírových (inflačních) marek. $\mathrm{K}$ zajištění její kredibility byla kryta aktivy ve výši 3200 mil. RM. Byly to především obligace státu na pozemkové vlastnictví státu a dodatečné garance německých bank (Moravcová, 2006). Měnová reforma se ukázala jako úspěšná a 30. srpna následujícího roku byla zavedena zlatá marka, tedy měna se stanoveným zlatým obsahem.

Berlín financoval pasivní odpor v Porúří pomocí deficitního rozpočtu. Byly kompenzovány příjmy ušlé jak zaměstnancům, tak podnikatelům. Je pravdou, jak podotýká Wiedemann (1927), že škody způsobené pasivním odporem nikdy nebyly plně vládou nahrazeny a vláda zafinancovala podnikům $\mathrm{v}$ různých odvětvích zhruba 60-70 \% nákladů a ztrát, které utrpěly. Napríklad celkové škody na zisku dolů v rúrské oblasti, na jejich nucených dodávkách, byly vyčísleny kolem 730 mil. ř́šských marek, státem však byly pokryty do výše jen 556 mil. říšských marek. Podobně tomu bylo v chemickém průmyslu: škody zde činily asi 71 mil., ale od státu bylo zaplaceno jen asi 50 mil. Ačkoli byly všechny platby reparací v období rúrské krize Německem zastaveny, státní výdaje byly mnohem vyšší než předtím, jelikož náklady na financování pasivního odporu převyšovaly splátky reparací. Netřeba podotýkat, že př́ijmy státního rozpočtu byly $\mathrm{v}$ roce 1923 výrazně nižší než v předchozích letech.

Rúrská krize zatížila německou ekonomiku a státní pokladnu více než platby reparací. Podle odhadů se denní náklady na financování odporu pohybovaly $\mathrm{v}$ době nejhlubší krize, tj. v polovině záríi 1923, kolem 40 mil. zlatých marek, tj. asi 3500 bilionu inflačních marek (Prüfer a Tomin, 1962). Hrubé odhady nákladů a škod plynoucích z pasivního odporu, jež byly spočítány do konce záríi 1923 v mil. zlatých marek, poskytuje Schultze (1927):

Výpadek produkce v průmyslu a těžbě $\quad 1600$

Přerušení provozu dopravy 200

Zvýšené dovozy ze zahraničí

200
Škody vzniklé př́mým zásahem

(zabavení majetku, pokuty, daně, cla, atd.) 1000

Rozpočtové ztráty 2000

Celkem

$6200-6500$

Po ukončení pasivního odporu byla provedena nejen měnová reforma uvedená výše, ale i rozpočtová opatření směřující $\mathrm{k}$ racionalizaci výdajů a zvýšení př́ijmů. V rámci nich byla napríklad propuštěna čtvrtina státních zaměstnanců nebo sníženy podpory v nezaměstnanosti. Postupně se hospodaření státu (i v důsledku hospodářského oživení) zlepšovalo. V lednu 1924 činil rozpočtový deficit 2 mil. marek, ačkoli měsíc předtím to bylo 33 mil. marek, v březnu byl dokonce zaznamenán mírný přebytek. (O’Riordanová, 2001)

Německu hyperinflace přinesla dva pozitivní efekty - v důsledku vyšší inflace se neobjevila hospodáŕská recese a nezvyšovala se zde nezaměstnanost dokonce se někdy hovoři o zdánlivém rozkvětu $\mathrm{v}$ důsledku hyperinflace. Německá ekonomika nejdř́ve díky odvodům reparací (tedy nutnosti vyrábět a těžit), a poté i díky hyperinflaci neprodělala poválečnou depresi ani růst nezaměstnanosti. Mezi záŕím 1921 a ř́ijnem 1922 byla dokonce vykazována téměr̆ nulová nezaměstnanost, o čemž svědčí i údaje z roku 1922 v tabulce 2. Fischer (1984) uvádí, že mezi dubnem a záŕím 1922 činila míra nezaměstnanosti pouhé $1 \%$.

Rovněž v mezinárodním srovnání Německo nemělo s nezaměstnaností až do roku 1923 problémy. Naopak jiné země jí v důsledku poválečné deprese trpěly poměrně výrazně. Např́iklad ve Velké Británii byla v roce 1921 zaznamenána až 17\% míra nezaměstnanosti. Během počátečního období rúrské krize se nezaměstnanost více nezvyšovala především kvưli dávkám od státu (Lohnsicherung) a kvůli tomu, že lidé ve stávce byli placeni až do dvou třetin svého platu státem (Lohngesicherten) a nepovažovali se za nezaměstnané, a tudíž se ani takto neevidovali. Nezaměstnanost se začala znatelně zvyšovat de facto až od záŕí 1923 a to až na $28,2 \%$ v prosinci téhož roku.

Náklady na znovuspuštění závodů a náklady

vzniklé nevyužitím výrobních kapacit 1200 - 1500

Tabulka 1 Index velkoobchodních cen ve vybraných zemích $(1913=100)$

\begin{tabular}{|l|c|c|c|c|c|c|}
\hline Rok & \multicolumn{2}{|c|}{ Německo } & \multicolumn{2}{c|}{ Velká Británie } & \multicolumn{2}{c|}{ Francie } \\
\hline & $1913=100$ & předch. rok $=100$ & $1913=100$ & předch. rok =100 & $1913=100$ & předch. rok $=100$ \\
\hline 1920 & 1498 & 304 & 307 & 120 & 508 & 143 \\
\hline 1921 & 2067 & 138 & 197 & 64 & 344 & 68 \\
\hline 1922 & 28700 & 1388 & 159 & 81 & 326 & 95 \\
\hline 1923 & $2,4 \times 10^{9}$ & 8362369 & 159 & 100 & 417 & 128 \\
\hline 1924 & 142 & - & 166 & 104 & 487 & 117 \\
\hline
\end{tabular}

Pramen: Fischer (1984), vlastní výpočty 
Tabulka 2 Míra nezaměstnanosti ve vybraných zemích (v \%)

\begin{tabular}{|l|c|c|c|}
\hline Rok & Německo & Velká Británie & Francie \\
\hline 1920 & 3,8 & 3,2 & - \\
\hline 1921 & 2,8 & 17,0 & 5,0 \\
\hline 1922 & 1,5 & 14,3 & 2,0 \\
\hline 1923 & 10,2 & 11,7 & 2,0 \\
\hline
\end{tabular}

Pramen: Fischer (1984)

Pozn.: U Německa se údaje o nezaměstnaných týkají pouze členů odborů, u Francie se jedná nezaměstnané pouze v odvětví hornictví, stavebnictví a průmyslu. Údaje uvedené u Velké Británie jsou vytvořeny na základě pojištění $\mathrm{v}$ nezaměstnanosti.

\subsection{Ochromení průmyslové výroby a dopravy}

V souvislosti s pasivním odporem a opatřeními okupační správy byla zastavena nebo omezena významná část průmyslové produkce $\mathrm{v}$ rúrské pánvi. ${ }^{7}$ Byly přetrhány vazby $\mathrm{s}$ neobsazeným územím Německa a vnějším světem, jelikož byla Francouzi výrazně omezena doprava, byla zavedena cla na dovoz ze zahraničí. Vývoz některých komodit na území mimo Porúríi byl zcela zakázán nebo musel být výslovně povolen. Kontrolu nad doly a hutěmi převzala MICUM. Ačkoli regionální statistiky průmyslové produkce nejsou dostatečně kvalitní, a tudíž průkazné, o útlumu průmyslu svědčí např́klad statistika o provozu vysokých pecí. Jestliže v roce 1922 fungovalo 158 vysokých pecí dohromady 7008 týdnů, pak v roce 1923 to bylo 145 pecí po dobu 4730 týdnů. Průměrný počet týdnů na jednu pec $\mathrm{v}$ provozu se tak snízil o 12 (Wiedemann, 1927).

Propojení obsazených oblastí s neobsazeným Německem bylo před jejich uzavřením velmi úzké. Více než polovina zboží převáženého po německých železnicích nebo lodních cestách pocházela z obsazených oblastí nebo do nich směřovala (nejedná se pouze o Porúř́, ale všechny obsazené oblasti). Mezi nejvíce vyvážené komodity patřilo černé a hnědé uhlí, koks, železo a výrobky z něj, kolejnice, stroje, dále i průmyslová hnojiva či obecně výrobky chemického a textilního průmyslu. Naproti tomu do obsazených

\footnotetext{
${ }^{7}$ Obsazené oblasti Porýní a Porúř́ spolu se Sárskem tvořily podle materiálu říšského ministerstva financí (BA R43/212) téměř $85 \%$ celkové těžební kapacity Německa $\mathrm{v}$ černém uhlí, 77 \% kapacity železné rudy, 90 \% výroby koksu a $85 \%$ výroby oceli. O faktu, že se Porúŕí nacházelo v průmyslovém centru Německa, svědčí i statistika o struktuře zaměstnanosti na tomto území. Jestliže v Německu připadalo na zemědělství a lesnictví $31 \%$ zaměstnaných, v Porúŕí to bylo $22 \%$, naopak v průmyslu a hornictví byl celostátní průměr $38 \%$, v Porúŕí pak $50 \%$. Wiedemann (1927) uvádí, že až $23 \%$ veškerých německých dělníků pracovalo právě v Porúríi.
}

oblastí se dováželo surové železo a železná ruda, určené dále ke zpracování, a dřevo at' už důlní, at' stavební.

Železnice podléhaly vojenské kontrole a na obsazeném území (mimo kolínskou zónu) začala operovat francouzsko-belgická železnice Régie. Ta však dopravu nezvládala a docházelo ke ztrácení vlaků naložených zbožím a směřujících do Nizozemí, Švýcarska a dalších zemí. Velmi často se objevovaly dopravní zácpy a několikadenní zpoždění dodávek. Navíc byly přetěžovány méně frekventované trasy a především trasy nevedoucí přes rebelující území. Ochromena byla nejen doprava železniční, ale i lodní po Rýnu a Rúru. Wiedemann (1927) uvádí, že v Porýní se objem přepravovaného zboží snížil v roce 1923 ve srovnání s rokem 1922 na polovinu (23,4 mil. tun). V mezinárodním obchodě byly německé lodě částečně nahrazeny zahraničními lodními společnostmi.

Ukončení pasivního odporu umožnilo postupné obnovování dopravy na železnici, ovšem stále ještě pod vedením Régie. Dále byla uvolňována francouzsko-belgická represivní hospodářská opatření, byly zrušeny zákazy a cla na dovoz a vývoz. MICUM uzavírala již od zárí 1923 s místními podnikateli dohody o dodávkách uhlí. Německé doly na obsazených územích musely dodávat $27 \%$ své produkce a 10 \% vedlejších produktů, mimo to také platit daň z uhlí (a to i se zpětnou platností), továrny chemického průmyslu pak musely dodávat např. barvy, dusík apod. Celkem bylo do dodávek zapojeno až padesát různých průmyslových oborů. Tato situace se nezměnila až do zavedení Dawesova plánu v roce 1925. Celní svrchovanost Německa byla obnovena v zárí 1924, správa rúrského území stejně jako železnice byly předány Německu v polovině listopadu 1924.

\subsection{Ztráty $\mathbf{v}$ zahraničním obchodě}

Dopady rúrské okupace na zahraniční obchod Německa nelze zcela jednoznačně vyčíslit. Je třeba mít na paměti, že obchod výrazně ovlivňovalo nejen obsazení Porúríí, kdy byla západní hranice Německa kontrolována okupačními mocnostmi po téměř dva roky, ale i devalvace měny, stabilizační krize, úvěrová restrikce Řišské banky či také zahraniční protekcionistická opatření.

V kritickém roce 1923 je z naturálního vyjádření dovozu patrné jeho zvýšení (viz tabulka 3). V důsledku uzavření rúrské pánve musela neobsazená část Německa získávat potřebné suroviny a výrobky ze zahraničí. Naproti tomu se dramaticky zhoršil vývoz, kdy ani devalvace marky nedokázala kompenzovat výpadek produkce rúrských podniků. $\mathrm{Z}$ obou těchto skutečností plynula značná výše schodku obchodní bilance, kdy byl vývoz výrazně (více jak dvojnásobně) převýšen dovozem. V peněžním vyjádření je pak 
patrný výraznější propad dovozu v roce 1923, zatímco ten v roce 1924 se naopak zvýšil, vývoz dále pokračoval v poklesu, i když nižším tempem. Protichůdnost údajů o dovozu v naturálním a hodnotovém vyjádření lze vysvětlit mimo jiné pohybem cenových hladin.

Tabulka 3 Vývoz a dovoz Německa

\begin{tabular}{|c|c|c|c|c|}
\hline Rok & $\begin{array}{c}\text { Dovoz } \\
\text { (v mil. } \\
\text { tun) }\end{array}$ & $\begin{array}{c}\text { Dovoz } \\
\text { (v mil. } \\
\text { RM, s. c. } \\
\text { 1913) }\end{array}$ & $\begin{array}{c}\text { Vývoz } \\
\text { (v mil. } \\
\text { tun) }\end{array}$ & $\begin{array}{c}\text { Vývoz } \\
\text { (v mil. } \\
\text { RM, s. c. } \\
1913 \text { ) }\end{array}$ \\
\hline 1922 & 45,8 & 6290 & 21,6 & 6186 \\
\hline 1923 & 46,6 & 4808 & 12,7 & 5338 \\
\hline 1924 & 38,5 & 6769 & 15,8 & 5133 \\
\hline
\end{tabular}

Pramen: Wiedemann (1927)

Jednoznačným dopadem rúrské krize byla $\mathrm{v}$ oblasti zahraničního obchodu ztráta trhů - a to především evropských. Výpadek německých dodávek způsobil těžkosti v mnoha továrnách, a to jak u méně rozvinutých států, jako byly země Jižní Ameriky, tak i u těch rozvinutých jako Československo, Rakousko či Švýcarsko. Většinou se jednalo o nedodání potřebných surovin, strojů nebo výrobků či polotovarů železáŕského a hutnického průmyslu. Právě v komoditách, jejichž producentem bylo Porúrí, se projevovalo výrazné zhoršení německé bilance zahraničního obchodu.

Ilustrativním př́ikladem byl obchod s uhlím, $\mathrm{v}$ němž se $\mathrm{v}$ roce 1923 situace jednoznačně zhoršila. Jestliže Německo bylo ještě před válkou významným vývozcem uhlí, v roce 1923 se stalo čistým dovozcem. Dobývání uhlí se meziročně snížilo ze 160 mil. tun na téměř polovinu ( 88 mil. tun). Dovoz černého uhlí se naproti tomu výrazně zvýšil z 12,5 mil. tun na 25,3 mil. tun. O tom, že se jednalo o dočasnou záležitost vyvolanou okupací rúrské pánve, svědčí opětovný pokles dovozu v roce 1924 na 13,2 mil. tun. Schultze (1927) podotýká, že německý dovoz černého uhlí z Anglie činil v roce 1922 7,7 mil. tun, v roce 1923 byl zhruba dvojnásobný (15,7 mil. Tun), v roce 1924 pak poklesl zpět na 6 mil. tun. Z Polska to pak bylo 2,9 mil. tun, 8,7 mil. a 6,5 mil. tun v letech 1922, 1923 a 1924. Německo ztratilo svoji pozici ve vývozu uhlí v zemích jako Belgie, Francie a Nizozemí. Například vývoz německého uhlí do Francie poklesl o $60 \%$.

V obchodu s koksem docházelo k podobnému vývoji. Jestliže v roce 1922 bylo vyvezeno 908 mil. tun, v roce 1923 to bylo pouze 270 tis. tun. Dovoz se naopak zvýšil z 288 tis. tun na 1,5 mil. tun. Dramaticky poklesl i dovoz rud - železné z 11 mil. tun na pouhých 2,3 mil. tun, měděné ze 132 tis. tun na 49 tis. tun a zinkové z 73 tis. tun na 39 tis. tun (Wiedemann, 1927). Neméně závažné byly dopady v odvětvích textilního průmyslu (viz také kapitola Hospodářské důsledky pro Velkou Británii). O 20 \% poklesl dovoz bavlny a o $30 \%$ dovoz vlny. $\mathrm{V}$ důsledku výrazného omezení výroby v Porúríi Německo dováželo mnohem méně napríklad př́rodního kaučuku, a to až o třetinu v porovnání s rokem 1922. Na jedné straně znamenal útlum výroby v Porúří zvýšení náročnosti na dovozy některých komodit, na druhé straně zase přinesl pokles poptávky po dovozech jiného zboží. Je poměrně zřejmé, že pokles německé poptávky na zahraničních trzích $\mathrm{v}$ důsledku pasivního odporu vyvolával u dodávajících zemí snížení př́immů z vývozu i jejich kupní síly.

Mezi nejzávažnější důsledky rúrské krize $\mathrm{v}$ německé ekonomice lze zařadit hyperinflaci a devalvaci domácí měny, nadměrné zatížení státního rozpočtu v důsledku financování pasivního odporu, poněkud zpožděný růst nezaměstnanosti, a také zhoršení pozice německých výrobků na mezinárodních trzích, resp. zvýšení dovozní náročnosti německé ekonomiky a prohloubení deficitu obchodní bilance.

\section{Hospodářské důsledky pro Velkou Británii}

Situace v Porúř́i v průběhu roku 1923 přinesla britské ekonomice a především britskému zahraničnímu obchodu jak negativní, tak i pozitivní dopady. Mezi ty negativní makroekonomické dopady zcela jistě mohlo patřit vážné narušení obchodu $\mathrm{s}$ německou stranou. Obě země na sebe byly ekonomicky navázány a Velká Británie byla $\mathrm{v}$ některých odvětvích silně závislá na obchodní výměně s Německem. Mezi lety 1911-13 se Německo podílelo na britských exportech zhruba z 8,3 \%, v roce 1920 to bylo pouze $1,5 \%$ a v roce 1921 pak 2,4 \% (Marksová, 2003). Důvodem byla již zmiňovaná vysoká cla na vývoz a dovoz, zákaz vývozu a dovozu vybraného zboží a komodit a výpadek produkce rúrských podniků. Další negativum představoval také prudký růst ceny nerostných surovin - tedy nákladů pro (nejen) britské podnikatele a v konečném důsledku spotřebitele. Rozvrácení německé měny (a francouzského franku) znamenalo výrazný úbytek bohatství britských investorů, jestliže investovali $\mathrm{v}$ těchto měnách a do těchto evropských měn, které později výrazně devalvovaly. Obě tyto depreciace lze považovat za důsledek rúrské okupace $\mathrm{v}$ makroekonomickém měřítku.

\subsection{Pozitivní vývoj v odvětvích těžkého průmyslu}

Německé podniky představovaly významné konkurenty Velké Británie v jejích tradičních odvětvích - těžbě uhlí, železné rudy, výrobě železa a oceli a lodním stavitelství. Pozitivní mikroekonomické dopady francouzsko-belgického obsazení Porúŕí se projevily především $\mathrm{v}$ těch odvětvích britského průmyslu, která suplovala dřivější německý vývoz. Výrazně kladný vliv měla okupace na odvětví zabývající se těžbou a nakládáním s uhlím. Uzavření německých dolů jim 
poskytlo možnost expanze, která ale nebyla z kapacitních důvodů zcela využita. Tato odvětví zažívala svůj boom již před francouzsko-belgickou epizodou v Porúríi. Boom byl dán především celoevropskou obnovou průmyslových kapacit a stále více rostoucí závislostí na této surovině.

Již na počátku prosince 1922 se britská produkce uhlí zvýšila na 5,5 mil. tun týdně a dodávky uhlí zaznamenaly návrat na svou předválečnou úroveň (Busteed, 1927). Výpadek německých dolů sice zvýšil poptávku po britském uhlí, ale jelikož doly v Británii byly téměř plně využity, nemohly nabízené množství dostatečně navýšit, rostla proto výrazně cena. Požadavky, jež nemohly být uspokojeny, mírilly do Francie, Československa nebo Polska. Schultze (1927) uvádí, že největší prospěch z německého kolapsu vývozu uhlí měly právě Velká Británie, Československo a Polsko. V Československu zažívala odvětví spojená s uhlím boom. Stejný autor podotýká, že únoru 1923 se zvýšil vývoz uhlí do Německa o téměř $100 \%$. Ve vývozu koksu se Československu podařilo vývoz do Německa téměř ztrojnásobit na téměř 910 tis. tun v porovnání let 1922 a 1923.

Pro ilustraci situace $v$ uhelném odvětví jsou uvedeny tabulka 4 a tabulka 8 v př́loze. Z nich vyplývá, že za celý rok 1923 se objem nově vytěženého uhlí zvýšil o téměř $8 \%$, vývoz uhlí pak o $20 \%$ a vývoz koksu až o $35 \%$. Od druhé poloviny roku 1923 nebyl tlak poptávky již tak velký, jelikož v Porúř́i postupně docházelo $\mathrm{k}$ obnovování těžby mimo jiné i díky uzavírání dohod o dodávkách s MICUM. Přesto bylo v tomto roce dosaženo nejvyšší produkce za celé desetiletí, a to 278,5 mil. tun a tento objem převýšil produkci za rok 1922 o 26,5 milionu tun (Schultze, 1927). Za zhruba $60 \%$ tohoto převisu zodpovídala zvýšená zahraniční poptávka.

Schultze (1927) rovněž uvádí, že se zisk anglických uhlobaronů zvýšil z 10,4 mil. liber v roce 1922 až na 21,1 mil. liber v roce 1923 . Ovšem jak správně poznamenává, ke zvýšení ziskovosti v tomto sektoru nedošlo pouze díky rozšiřrováním stávajících kapacit, ale také díky výraznému nárůstu cen. Exportní ceny byly v roce 1923 až o více jak 12 \% vyšší ve srovnání s rokem předchozím, u koksu se mělo jednat o cenový nárůst až o třetinu. Ceny důležitých vývozních artiklů - uhlí, železa, oceli - ve Velké Británii kulminovaly v květnu 1923, poté se snižovaly až na úroveň prosince roku 1922. Té bylo dosaženo právě ke konci roku 1923. Např́ílad cena za tunu uhlí činila v lednu 1923 £1 2s. 5d., v květnu £1 7s. 7d., v prosinci £1 4s. 5d. V průměru za rok 1923 se platilo za tunu uhlí £1 5s. 1d., ačkoli v roce 1922 to bylo $112 \mathrm{~s}$. 7d (Busteed, 1927).

Tabulka 4 Vývoz koksu a syntetických paliv

\begin{tabular}{|l|c|c|}
\hline Rok & v tis. tun & hodnota (v tis. £) \\
\hline 1913 & 3288 & 2932 \\
\hline 1922 & 3741 & 5204 \\
\hline 1923 & 5037 & 10099 \\
\hline
\end{tabular}

Pramen: Busteed (1927)

Z hlediska teritoriální struktury se $\mathrm{v}$ porovnání s rokem 1922 nejvíce zvýšil vývoz uhlí do Belgie o $86 \%$, Německa o 78 \%, do Francie o 38 \%, Itálie o $21 \%$. Rok 1924 již nebyl tak úspěšný a produkce uhlí nedosahovala ani produkce roku 1922. Britské hospodářství se muselo potýkat $\mathrm{s}$ čím dál více se zvyšující konkurencí, a to nejen z Německa, ale také z Francie a Belgie.

Stejně jako tomu bylo $\mathrm{v}$ odvětvích spojených s těžbou uhlí, také ve výrobě železa a oceli výpadek německé produkce výrazně pomohl opět výše jmenovaným třem zemím. Vývoz polských kovových výrobků se rapidně zvýšil z 10,8 tis. tun v lednu 1923 až na téměř 45 tis. tun v březnu 1923, v následujících měsících se ale přechodně vyšší poptávka vyčerpala. Obdobné výsledky vykazoval v uvedených artiklech i československý vývoz, kterému se podařilo dosáhnout nejvyššího vývozu do Německa ve třetím čtvrtletí roku 1923. Z níže uvedené tabulky 5 nejvýznamnějších exportérů železné rudy a oceli je patrné, že ve srovnání prvních dvou čtvrtletí roku 1923 a 1922 došlo k největšímu navýšení vývozu železné rudy a oceli o 62 tis. tun u Velké Británie. Československo zvýšilo svoji vývozní produkci o 40 tis. tun, Rakousko

Tabulka 5 Vývoz železné rudy, oceli a obdobného zboží (v tis. tun)

\begin{tabular}{|l|c|c|c|c|c|c|c|}
\hline \multirow{2}{*}{ Měsíční průměr } & \multicolumn{3}{|c|}{ Profitující země } & \multicolumn{4}{c|}{ Tratící země } \\
\cline { 2 - 8 } & $\begin{array}{c}\text { Velká } \\
\text { Británie }\end{array}$ & Rakousko & $\begin{array}{c}\text { Českoslo- } \\
\text { vensko }\end{array}$ & USA & Francie & $\begin{array}{c}\text { Belgie, } \\
\text { Lucembursko }\end{array}$ & \begin{tabular}{c} 
Německo \\
\hline 1920
\end{tabular} \\
271 & 15 & 14 & 392 & 75 & - & 143 \\
\hline 1921 & 142 & 16 & 17 & 181 & 133 & - & 152 \\
\hline 1. pol. 1922 & 256 & 16 & 17 & 183 & 129 & 94 & 201 \\
\hline 2. pol. 1922 & 310 & 22 & 15 & 274 & 197 & 192 & 216 \\
\hline 1. čtvrt. 1923 & 346 & 26 & 33 & 140 & 171 & 187 & 168 \\
\hline 2. čtvrt. 1923 & 372 & 27 & 55 & 182 & 126 & 185 & 102 \\
\hline
\end{tabular}

Pramen: Schultze (1927) 
o 7 tis. tun. Naproti tomu USA vyvezly o 92 tis. tun méně, Francie o 71 tis. tun méně. Výrazný propad lze pozorovat u Německa o 114 tis. tun.

Oživení produkce železa a oceli ve Velké Británii opět úzce souviselo $\mathrm{s}$ částečným přerušením dodávek z hutnických závodů z Německa. Velice podobným vývojem procházela i navazující odvětví metalurgie. Vysokých pecí v činnosti bylo na počátku ledna 1923 asi 170 , na konci května pak 223. Měsíční produkce surového železa se zvýšila nejvíce $\mathrm{v}$ období mezi lednem a květnem 1923 z 568 tis. tun na 714 tis. tun, oceli pak z 634 tis. tun na 821 tis. tun (Busteed, 1927). $\mathrm{Z}$ hlediska ročních údajů pak došlo ke zvýšení produkce o více jak 50 \% u surového železa a o $46 \%$ u oceli. Vývoz železa a oceli vzrostl z 3400 tis. tun v roce 1922 na 4300 tis. v roce 1923. Podrobnější vývoj po měsících roku 1923 popisuje tabulka $9 \mathrm{v}$ př́loze.

\subsection{Protiklady $v$ britském zahraničním obchodě}

$\mathrm{V}$ britské ekonomice docházelo $\mathrm{k}$ protichůdným tendencím, kdy se na jedné straně některá odvětví rozvíjela a vykazovala růst výroby, jestliže byl hlavní konkurent ochromen. Na straně druhé, jiná proexportně orientovaná odvětví nebo odvětví dovozně náročná naopak zažívala úpadek, jednalo se například o obchod s vlnou. Nejvýznamnějším dovozcem britské bavlny bylo právě Německo. Německo dovezlo v roce 1923 téměř o polovinu méně bavlny a vlny než $\mathrm{v}$ předchozím roce (v hodnotě 59,7 mil. liber oproti 103,9 mil. liber). Podobně se propadl import vlněné prríze, a to nejen do Německa, ale např́iklad také do Francie a Belgie. Př́iznivý vývoj v těžkém průmyslu ale převážil a $\mathrm{v}$ celkovém pohledu se bilance zahraničního obchodu Velké Británie v roce 1923 s Německem zlepšila. Převis vývozu nad dovozem se zvýšil z 22,5 mil. £ v roce 1922 na 25,8 mil. £ v roce 1923, což plyne z tabulky 6.

Naopak v obchodu s Francií a Belgií to bylo přesně naopak - přebytek obchodní bilance se snížil o 8 mil. £, resp. o téměř 4 mil. £. (Busteed, 1927) Rúrská krize téměř neovlivnila situaci $\mathrm{v}$ dovozu uhlí a železné rudy do Velké Británie - napr. dovoz železné rudy byl zabezpečován mimo Německo - ze zemí jako Alžír, skandinávských zemí či Španělska. Velká Británie disponovala také svými rozsáhlými ložisky železné rudy a jejich těžbu zvýšila v roce 1923 meziročně o více jak $60 \%$.

Je zřejmé, že Velká Británie podobně jako za první světové války těžila ze své nezávislosti na obou stranách konfliktu. Rozmach zaznamenala těžby uhlí, výroba koksu, zpracování železné rudy a produkce oceli. Britští producenti a vývozci v těchto odvětvích profitovali na zvýšení cen, které bylo taženo poptávkou. Přesto se ale $\mathrm{v}$ zahraničním obchodě Velké Británie projevil $\mathrm{v}$ některých komoditách útlum. Zcela žádné výhody nezískaly z rúrské krize britské kolonie a dominia, která musela platit vyšší sumy za dovážené nerostné suroviny mateřské zemi $\mathrm{v}$ důsledku zvýšených cen.

\section{Závěr}

Velice komplikovaná jednání o reparacích a také jejich složité vymáhání na Německu významně ovlivňovaly dění na mezinárodní politické scéně. Pochopitelně se vyrovnávání válečných dluhů značně projevovalo i v ekonomikách jednotlivých zemí. Neschopnost domluvit se na posuzování otázky reparací na nejen politickém, ale i ekonomickém základě vyvrcholilo obsazením rúrské oblasti Francouzi a Belgičany v lednu 1923. Cílem bylo zajistit si pravidelné odvody splátek a hmotné dodávky nerostných surovin, kterým Německo nebylo schopno dostát mírovou cestou. Německo reagovalo vyhlášením politiky pasivního odporu. Tyto kroky se však Německu a Francii vymstily nejen hospodářsky, ale i politicky. Obě země se hospodářsky velmi brzo vyčerpaly, aniž by strhly vítězství na svoji stranu.

Velkou roli v debatách před okupací Porúríi a během ní hrála Velká Británie, která svým mnohdy nerozhodným postojem nahrávala nesmiŕlivým postojům francouzské vlády. Lze říci, že to byla právě Velká Británie, která celou dobu držela v ruce klíč nejen k odvrácení rúrské krize, ale také $\mathrm{k}$ jejímu řešení. Její jasný postoj mohl francouzskou zahraniční politiku vi̊či Německu nastavit jiným směrem nebo ji alespoň zmírnit. Rovněž Německo mohlo být přinuceno k placení reparací jinak než silou. Nestalo se tak a Německo bylo nuceno projít si obdobím závažné politické i ekonomické nestability, které v mnohém předurčilo jeho následný, především politický, vývoj.

Tabulka 6 Obchodní bilance Velké Británie s Německem, Francií a Belgií

\begin{tabular}{|l|c|c|c|c|}
\hline \multirow{2}{*}{ Země } & \multicolumn{2}{|c|}{1922} & \multicolumn{2}{c|}{1923} \\
\cline { 2 - 5 } & vývoz (v mil. £) & čistý dovoz (v mil. £) & vývoz (v mil. £) & čistý dovoz (v mil. £) \\
\hline Německo & 32076 & 9539 & 42570 & 16735 \\
\hline Francie & 48310 & 30992 & 49258 & 39435 \\
\hline Belgie & 13009 & 24831 & 25211 & 17241 \\
\hline
\end{tabular}

Pramen: Busteed (1927) 
Několikaměsíční patová situace okolo rúrské krize významným způsobem zapř́čiňovala devastaci německého hospodářství. Německo si prodělalo hyperinflaci a kolaps domácí měny, které částečně souvisely s financováním pasivního odporu rúrských podniků a pracujících vládou. Útlum ve výrobě se dotýkal především podniků těžkého průmyslu soustředěných $\mathrm{v}$ rúrské oblasti. V návaznosti na to vzrostly požadavky německých podniků na dovoz, jenž suploval domácí dodavatele. Také vývoz se snížil díky odříznutí Porúří od německé ekonomiky. Neméně závažný dopad představovala také ztráta obchodních pozic na trzích doma i v zahraničí.

Velkou Británii lze naproti tomu považovat spíše za hospodářského vítěze tohoto konfliktu. Vybraná britská odvětví, především těžkého průmyslu, těžila z výpadku německých vývozů. Jednalo se např́klad o těžbu uhlí, železné rudy, výrobu oceli. Díky poklesu nabídky a růstu poptávky se produkce těchto odvětví prodávala za mnohem vyšší ceny než dř́ive, což britským průmyslníkům přinášelo vysoké zisky. Jiná odvětví naopak ztrácela - např. textilní průmysl, jelikož se redukovala (německá) poptávka po jejich zboží. V celkovém pohledu ale byly negativní dopady marginální a Velké Británii se podařilo prosadit se na zahraničních trzích na úkor německých vývozců.

\section{Literatura}

BALDERSTON, T. (2002). Economics and Politics in Weimar Republic. Cambridge: Cambridge University Press.

BUSTEED, J. (1927). Der Einfluß der Ruhrbesetzung auf das Wirtschaftsleben Großbritanniens und der Britischen Besitzungen. In: SCHULTZE, E.: Ruhrbesetzung und Weltwirstchaft: Eine Internationale Untersuchung der Auswirkungen der Ruhrbesetzung auf die Weltwirschaft. Schriften des WirtschaftsInstituts der Handeln-Hochschule Leipzig. Leipzig: Glöckner Verlagsbuchbehandlung in Leipzig: 99-103.

EYCK, E. (1954). Geschichte der Weimarer Republik. Von Zusammenbruch des Kaisertums bis zur Wahl Hindenburgs. Erlenbach-Zürich: Eugen Rentsch Verlag.

FISCHER, C. (2003). The Ruhr Crisis 1923-24. Oxford: Oxford University Press.

FISCHER, W. (1984). Wirstchaftliche Rahmenbedigungen des Ruhrkonfikts. In: SCHWABE, K.: Die Ruhrkrise 1923, Wendepunkt der internationalen Beziehungen nach dem Ersten Weltkrieg. Paderborn: Ferdinand Schöningh Verlag: 89-101.

HÜRTEN, H. (2003). Deutsche Geschichte in Quellen und Darstellung. Weimarer Republik und Drittes Reich 1918-45. Stuttgart: Phillips Reclam GmbH \& Co.
JORDAN, W.M. (1971). Great Britain, France, and the German Problem 1918-1939. A Study of AngloFrench Relations in the Making and Maintenance of the Versailles Settlement. London: Frank Cass \& Co. Ltd.

KUHNHEIM, H. (1929). Die Wirkungen der Ruhrbesetzung auf der Wirtschaft und Politik Großbritanniens. Disertační práce. Berlin: Friedrich Wilhelm Universität.

LOWE, J. (1994). The Great Powers Imperialism and the German Problem 1865-1925. London: Routledge.

MARKSOVÁ, S. (2003). The illusion of peace: International relations in Europe, 1918-1933. New York: Houndmills, Palgrave Macmillan.

MICHALKA, W. (1987). Deutsche Außenpolitik 1920-1933. In: BRACHER, K.D., FUNKE, M.J.: Die Weimarer Republik 1918-1933. Politik, Wirtschaft, Gesellschaft. Studien zu Geschichte und Politik. Bonn: Bundeszentrale für politische Bildung: 303326.

MEYER, G. (1987). Die Reparationspolitik. Ihre außen- und innenpolitischen Rückwirkungen. In: BRACHER, K.D., FUNKE, M.J.: Die Weimarer Republik 1918-1933. Politik, Wirtschaft, Gesellschaft. Studien zu Geschichte und Politik. Bonn: Bundeszentrale für politische Bildung: 327-342.

MORAVCOVÁ, D. (2006). Výmarská republika. Problémy demokracie v Némecku 1918-1932. Praha: Univerzita Karlova v Praze.

MORAVCOVÁ, D., BĚLINA, P. (1998). Kapitoly z dějin mezinárodních vztahů 1914-1941. Praha: Institut pro středoevropskou kulturu.

O‘RIORDANOVÁ, E. (2001). Britain and the Ruhr Crisis. New York: Houndmills, Palgrave.

PAWLEYOVÁ, M. (2007). The Watch on the Rhine, The Military Occupation of the Rhineland, 19181930. New York: Palgrave Macmillan.

PRÜFER, G., TOMIN, W. (1962). Die Entstehung und Entwicklung der Weimarer Republik bis zu Eberts Tod. Hefte zum Zeitgeschehen, Heft 2. Hannover: Verlag für Literatur und Zeitgeschehen GmbH Hannover.

RUGE, W. (1982). Deutschland von 1917 bis 1933 (Von Großen Sozialistischen Oktoberrevolution bis zum Ende der Weimarer Republik). Zentralinstitut für Geschichte der Akademie der Wissenschaften der DDR. Berlin: VEB Deutscher Verlag der Wissenschaften. 
SCHULTZE, E. (1927). Ruhrbesetzung und Weltwirtschaft. In: SCHULTZE, E.: Ruhrbesetzung und Weltwirstchaft: Eine Internationale Untersuchung der Auswirkungen der Ruhrbesetzung auf die Weltwirschaft. Schriften des Wirtschafts-Instituts der HandelnHochschule Leipzig, Leipzig: Glöckner Verlagsbuchbehandlung in Leipzig: 187-211.

STEITZ, W. (1993). Quellen zur deutschen Wirtschafts- und Sozialgeschichte vom ersten Weltkrieg bis Ende der Weimarer Republik. Ausgewählte Quellen zur deutschen Geschichte der Neuzeit. Darmstadt: Wissenschaftliche Buchgesellschaft.

VON WUTHENAU, A. (1924). Okkupationslehre und Ruhrbesetzung, eine völkerrechtlige Studie. Kiel: Christian Albrechts Universität zu Kiel.
WIEDEMANN, A. (1927). Die Wirkungen der Ruhrbesetzung auf die deutsche Volkswirtschaft. In: SCHULTZE, E.: Ruhrbesetzung und Weltwirstchaft: Eine Internationale Untersuchung der Auswirkungen der Ruhrbesetzung auf die Weltwirschaft. Schriften des Wirtschafts-Instituts der Handeln-Hochschule Leipzig. Leipzig: Glöckner Verlagsbuchbehandlung in Leipzig: 11-28.

\section{Další zdroje}

Archivní materiály z Bundesarchivu BerlinLichterfelde, fondy Akten der Reichskanzlei (R43, R43-I), Rheinische Volkspflege (R1603)

\section{Př́lohy}

Tabulka 7 Měnový kurz německé marky k dolaru (měsíční průměry), index znehodnocení měny v Německu

\begin{tabular}{|l|c|c|c|}
\hline Období & Měnový kurz k USD & $\begin{array}{c}\text { Znehodnocení měny podle } \\
\text { devizových kurzů }\end{array}$ & $\begin{array}{c}\text { Znehodnocení měny podle } \\
\text { velkoobchodních cen }\end{array}$ \\
\hline Leden 1919 & 8,9 & - & - \\
\hline Leden 1920 & 64,8 & 15,4 & 12,6 \\
\hline Leden 1921 & 64,9 & 15,4 & 14,4 \\
\hline Leden 1922 & 191,8 & 45,7 & 36,7 \\
\hline Červenec 1922 & 493,2 & 117,0 & 101,0 \\
\hline Leden 1923 & 17972,0 & 4279,0 & 2785,0 \\
\hline Červenec 1923 & 353412,0 & 84150,0 & 74787,0 \\
\hline Srpen 1923 & 4620455,0 & 1100100,0 & 944041,0 \\
\hline Září 1923 & 98860000,0 & 23540000,0 & 23949000,0 \\
\hline Ŕ́ijen 1923 & 25260208000,0 & 6014300000,0 & 7095800000,0 \\
\hline 15. ř́jjen 1923 & 4200000000000,0 & 1000000000000,0 & 750000000000,0 \\
\hline
\end{tabular}


Tabulka 8 Vývoz uhlí z Velké Británie po měsících v roce 1923, celkem v roce 1913, 1922 a 1923

\begin{tabular}{|l|c|c|c|}
\hline \multirow{2}{*}{ Období } & \multicolumn{2}{|c|}{ Nově vytěžé uhlí } & Celkový vývoz \\
\cline { 2 - 4 } & v tis. tun & hodnota (v tis. £) & 7331 \\
\hline Leden 1923 & 5612 & 6296 & 7307 \\
\hline Únor 1923 & 5903 & 6849 & 8624 \\
\hline Březen 1923 & 7180 & 8818 & 8269 \\
\hline Duben 1923 & 6841 & 8915 & 9244 \\
\hline Květen 1923 & 7648 & 10588 & 8150 \\
\hline Červen 1923 & 6589 & 8950 & 8144 \\
\hline Červenec 1923 & 6767 & 8841 & 8041 \\
\hline Srpen 1923 & 6580 & 8315 & 7809 \\
\hline Září 1923 & 6316 & 7824 & 9152 \\
\hline Ř́ijen 1923 & 7433 & 9110 & 8207 \\
\hline Listopad 1923 & 6670 & 8154 & 7328 \\
\hline Prosinec 1923 & 5874 & 7176 & 97608 \\
\hline Celkem za rok 1923 & 79450 & 99836 & 94457 \\
\hline Celkem za rok 1913 & 64198 & 50727 & 72529 \\
\hline Celkem za rok 1922 & 73400 & & \\
\hline
\end{tabular}

Pramen: Busteed (1927)

Tabulka 9 Produkce surového železa a oceli ve Velké Británii letech 1922 a 1923

\begin{tabular}{|c|c|c|c|c|c|}
\hline \multirow[t]{2}{*}{ Období } & \multicolumn{2}{|c|}{ Surové železo (v tis. tun) } & \multicolumn{2}{|c|}{ Ocel (v tis. tun) } & \multirow{2}{*}{$\begin{array}{c}\text { Vývoz surového železa } \\
\text { a oceli (v tis. tun) } \\
1923 \\
\end{array}$} \\
\hline & 1922 & 1923 & 1922 & 1923 & \\
\hline Leden & 288 & 568 & 328 & 634 & 353 \\
\hline Únor & 300 & 543 & 419 & 707 & 318 \\
\hline Březen & 390 & 634 & 549 & 803 & 368 \\
\hline Duben & 394 & 652 & 404 & 749 & 387 \\
\hline Květen & 408 & 714 & 462 & 821 & 425 \\
\hline Červen & 369 & 693 & 400 & 768 & 365 \\
\hline Červenec & 399 & 655 & 473 & 640 & 308 \\
\hline Srpen & 412 & 600 & 528 & 568 & 324 \\
\hline Září & 430 & 559 & 556 & 695 & 334 \\
\hline Říjen & 482 & 596 & 565 & 702 & 389 \\
\hline Listopad & 494 & 598 & 601 & 750 & 395 \\
\hline Prosinec & 534 & 627 & 546 & 653 & 355 \\
\hline Celkem & 4890 & 7439 & 5830 & 8489 & 4320 \\
\hline Průměr & 408 & 620 & 486 & 707 & 360 \\
\hline
\end{tabular}

Pramen: Schultze (1927), Kuhnheim (1929) 